\title{
Pemberdayaan Masyarakat Melalui Ekowisata Mangrove (Suatu Kajian di Kawasan Hutan Mangrove Wonorejo, Kecamatan Rungkut, Pantai Timur Surabaya)
}

\author{
Pricillia Azhani a*, Moh. Hasroel Thayib a, Hadi S. Alikodra ${ }^{\text {b }}$ \\ a Program Studi Ilmu Lingkungan, Fakultas Pascasarjana, Universitas Indonesia, Jl. Salemba Raya No.4 Jakarta \\ Pusat \\ ${ }^{b}$ Departemen Konservasi Hutan, Fakultas Kehutanan, Institut Pertanian Bogor, Jl. Lingkar Akademik, Babakan, \\ Bogor Tengah, Jawa Barat \\ *Email: priza_azhani@yahoo.com
}

Diterima (received) 3 Januari 2018; disetujui (accepted) 31 Januari 2019; tersedia secara online (available online) 1 Februari 2019

\begin{abstract}
Implementation of mangrove ecotourism development which is not suitable with ecotourism concept namely conservation and improvement of people's well-being, so that people can not increase their capacity for social, economic, and ecological independence. The research problems is the lack analysis of communities empowerment through Ecotourism Mangrove Wonorejo (EMW) activities. The main purpose of this study to analyze the communities empowerment through Ecotourism Mangrove Wonorejo (EMW) activities. This research use a quantitative approach with a qualitative and quantitative methods. Data collection instrument are using questionnaire, interview guides, and field observations with tabulation and descriptive analysis. The research results of social empowerment, respondents attend socialization and self improvement training qualification $88 \%$ and $83 \%$ of respondents simply do the task without any participation in the management and monitoring of EMW activities, in economic empowerment $100 \%$ of respondents earn increased revenue but can not create new job opportunities in EMW activities, in ecology empowerment, respondents do not recycle plastic waste, do not process organic waste, and do not conduct electricity and water efficiency $(0 \%)$. The conclusion is the community do not yet have the ability to make decisions and implement decisions to achieve the goal of public welfare.
\end{abstract}

Keywords: community development; ecotourism; mangrove; community welfare

\begin{abstract}
Abstrak
Pelaksanaan pengembangan ekowisata mangrove tidak sesuai dengan konsep ekowisata yaitu konservasi dan peningkatan kesejahteraan masyarakat, sehingga masyarakat belum dapat meningkatkan kapasitas diri untuk mandiri secara sosial, ekonomi, dan ekologi. Rumusan masalah dalam penelitian ini adalah belum adanya analisis mengenai pemberdayaan masyarakat melalui kegiatan Ekowisata Mangrove Wonorejo (EMW). Tujuan penelitian ini adalah untuk menganalisis pemberdayaan masyarakat melalui kegiatan Ekowisata Mangrove Wonorejo (EMW). Penelitian ini menggunakan pendekatan kuantitatif dengan metode kuantitatif dan kualitatif. Instrumen pengumpulan data menggunakan kuesioner, pedoman wawancara, dan pengamatan lapang yang dianalisis secara tabulasi dan deskriptif. Hasil penelitian adalah pada pemberdayaan sosial, responden mengikuti sosialisasi dan pelatihan peningkatan kualifikasi diri $88 \%$ dan $83 \%$ responden hanya melakukan tugas tanpa ada partisipasi dalam pengelolaan dan pengawasan kegiatan EMW, pemberdayaan ekonomi $100 \%$ responden mendapatkan peningkatan pendapatan namun belum dapat menciptakan lapangan pekerjaan baru dari kegiatan EMW, pemberdayaan ekologi responden tidak melakukan daur ulang sampah plastik, tidak mengolah sampah organik, serta tidak melakukan efisiensi air dan listrik (0\%). Kesimpulan adalah masyarakat belum memiliki kemampuan untuk mengambil keputusan dan melaksanakan keputusan untuk mencapai tujuan kesejahteraan masyarakat.
\end{abstract}

Kata Kunci: pemberdayaan masyarakat; ekowisata; mangrove; kesejahteraan masyarakat

doi: https://doi.org/10.24843/blje.2019.v19.i01.p03

(C) 2019 by the authors; Content from this work may be used under the terms of the Creative Commons Attribution 3.0 licence. Any further distribution of this work must maintain attribution to the author(s) and the title of the work, journal citation and DOI. Published under licence by Udayana University, Indonesia. 


\section{Pendahuluan}

Pertumbuhan penduduk menjadi salah satu faktor pendorong terjadinya pengembangan wilayah di sekitar pesisir. Rata-rata laju pertumbuhan penduduk di Kota Surabaya tahun 2009-2013 adalah 1,40\% per tahun (diolah dari BPS, 2015). Pantai Timur Surabaya (Pamurbaya) adalah sebuah kawasan konservasi mangrove di Surabaya. Kawasan Pamurbaya memiliki panjang pantai kurang lebih 14,4 km yang merupakan pantai berlumpur berhadapan langsung dengan Selat Madura. Keanekaragaman jenis mangrove di Surabaya tergolong tinggi, hal tersebut diketahui dari jumlah spesies mangrove Pantura (Pantai Utara Surabaya) dan Pamurbaya mencapai 22 jenis mangrove sejati dan 14 jenis mangrove asosiasi (BLH, 2013). Hutan mangrove di kawasan Pamurbaya, berfungsi sebagai sarana pendidikan lingkungan hidup, riset, dan wisata. Wisata ekologi atau ekowisata menjadi salah satu alternatif pemanfaatan kawasan mangrove. Ekowisata adalah suatu perjalanan yang bertanggung jawab pada lingkungan alami yang mendukung konservasi dan meningkatkan kesejahteraan penduduk setempat (Yoeti, 2000).

Pemberdayaan adalah sebuah proses interaktif yang terjadi antara individu dengan lingkungannya, adanya perubahan rasa tidak berdaya berubah pada penerimaan diri sebagai warga negara yang memiliki kemampuan sosial (Sadan, 2004). Kemajuan dalam hasil pengembangan masyarakat memberikan kontribusi untuk peningkatan kapasitas (Phillips and Pittman, 2009). Pemberdayaan masyarakat menjadi kunci utama pariwisata berkelanjutan, karena pemberdayaan dan keterlibatan masyarakat dalam berpatisipasi untuk menjaga budaya dan alam akan tercapai dan terjaga sehingga dapat berkelanjutan. Pengembangan pariwisata dan pemberdayaan masyarakat adalah bagian dari kesejahteraan masyarakat (Sutawa, 2012). Kesejahteraan masyarakat sekitar melalui kegiatan ekowisata dapat diperoleh dengan adanya kemauan dan kemampuan masyarakat untuk meningkatkan kapasitas diri sebagai bagian dari pembangunan kapasitas. Kegiatan EMW dapat meningkatkan kesejahteraan masyarakat apabila dilakukan secara sosial, ekonomi, dan ekologi untuk keberlanjutan kegiatan EMW dan pemberdayaan masyarakat itu sendiri. Pemangku kepentingan khususnya pengelola EMW dan pemerintah perlu melibatkan masyarakat secara penuh dalam kegiatan EMW baik dalam perencanaan, pengelolaa, dan pengembangannya. Berdasarkan latar belakang tersebut maka rumusan masalah dalam penelitian ini adalah belum adanya analisis mengenai pemberdayaan masyarakat melalui kegiatan Ekowisata Mangrove Wonorejo (EMW). Tujuan penelitian ini adalah untuk menganalisis pemberdayaan masyarakat melalui kegiatan Ekowisata Mangrove Wonorejo (EMW).

\section{Metode}

Penelitian ini dilaksanakan selama tiga bulan, pada bulan Juli sampai dengan Oktober 2015. Lokasi penelitian berada di ekowisata kawasan hutan mangrove Kelurahan Wonorejo, Kecamatan Rungkut, Kota Surabaya, Jawa Timur atau biasa disebut dengan Ekowisata Mangrove Wonorejo (EMW). Populasi adalah semua penduduk Kelurahan Wonorejo yang terlibat langsung pada kegiatan ekowisata. Penentuan sampel menggunakan teknik sampling jenuh atau sensus, dimana semua anggota populasi digunakan menjadi sampel. Sampel masyarakat yang terlibat langsung berjumlah 41 orang.

Pengumpulan data dilakukan dengan menggunakan kuesioner, pedoman wawancara, dan pengamatan lapang. Kuesioner menggunakan skala Guttman untuk mendapatkan jawaban yang tegas dari responden. Pemberian skoring pada variabel yang diukur memiliki dua interval, yaitu:

a. Ya dengan skor 1,

b. Tidak dengan skor 0 .

Jumlah skor ideal (kriterium) untuk setiap pertanyaan adalah satu (1) dan dikalikan dengan jumlah responden sebanyak 41 orang, sehingga didapatkan hasil 41 jika menjawab ya semua, jika ada responden yang menjawab tidak maka diberi skor nol (0). Pengolahan data hasil kuesioner dilakukan pembobotan pada setiap pertanyaan yang telah diajukan dan dilakukan tabulasi menggunakan software Microsoft Excel. Hasil pembobotan kemudian dihitung persentasenya. Analisis pemberdayaan masyarakat juga dilakukan dengan wawancara terstruktur untuk mengetahui pendapat responden lebih lanjut mengenai 
pertanyaan yang diajukan. Jawaban yang diberikan oleh responden digunakan sebagai data kualitatif yang dapat memperkuat jawaban responden.

\section{Hasil}

Hasil kuesioner yang disebarkan pada masyarakat menurut kelompok pekerjaan terdiri atas: pegawai ekowisata, pedagang kaki lima (PKL), parkir, dan kelompok tani (tujuh jenis pekerjaan). Tabulasi responden yang terlibat dalam kegiatan ekowisata dalam dilihat pada Tabel 1.

Tabel 1. Tabulasi Hasil Kuesioner Masyarakat

\begin{tabular}{|c|c|c|c|c|}
\hline \multirow{2}{*}{ No. } & \multirow{2}{*}{ Jenis Pertanyaan } & \multicolumn{3}{|l|}{ Hasil Kuesioner } \\
\hline & & & (n) & $(\%)$ \\
\hline \multicolumn{5}{|c|}{ Sosial } \\
\hline \multirow[t]{2}{*}{1.} & Pekerjaan sesuai kualifikasi & Ya & 35 & 85,37 \\
\hline & & Tidak & 6 & 14,63 \\
\hline \multirow[t]{2}{*}{2.} & Mendapatkan pelatihan & $\mathrm{Ya}$ & 36 & 87,80 \\
\hline & & Tidak & 5 & 12,20 \\
\hline \multirow[t]{2}{*}{3.} & Pelatihan mengolah mangrove & $\mathrm{Ya}$ & 20 & 48,78 \\
\hline & & Tidak & 21 & 51,22 \\
\hline \multirow[t]{3}{*}{4.} & Partisipasi kegiatan ekowisata & Pengelolaan dan pengawasan, & 3 & 7,00 \\
\hline & & Pengawasan saja, & 4 & 10,00 \\
\hline & & $\begin{array}{c}\text { Hanya melakukan tugas sesuai } \\
\text { pekerjaan. }\end{array}$ & 34 & 83,00 \\
\hline \multirow[t]{5}{*}{5.} & Keterlibatan pelestarian mangrove & $\begin{array}{c}\text { Pembibitan, penanaman, dan } \\
\text { pemeliharaan ekosistem mangrove, }\end{array}$ & 28 & 68,00 \\
\hline & & $\begin{array}{l}\text { Penanaman dan pemeliharaan } \\
\text { ekosistem mangrove, }\end{array}$ & 3 & 7,00 \\
\hline & & Pemeliharaan ekosistem mangrove, & 2 & 5,00 \\
\hline & & Tidak terlibat dalam pelestarian. & 8 & 20,00 \\
\hline & & Ekonomi & & \\
\hline 6. & Peningkatan pendapatan & $\mathrm{Ya}$ & 41 & 100 \\
\hline \multirow[t]{4}{*}{7.} & Pendapatan responden & $0-1$ juta rupiah & 2 & 4,90 \\
\hline & & $1-2$ juta rupiah & 16 & 39,00 \\
\hline & & $2-3$ juta rupiah & 22 & 53,70 \\
\hline & & Lebih dari 3 juta rupiah & 1 & 2,40 \\
\hline \multirow[t]{2}{*}{8.} & Bergantung pada EMW & Ya & 36 & 88,00 \\
\hline & & Tidak & 5 & 12,00 \\
\hline \multirow[t]{3}{*}{9.} & Memanfaatkan mangrove (komersil) & $\mathrm{Ya}$ & 1 & 2,40 \\
\hline & & Tidak & 40 & 97,60 \\
\hline & & Ekologi & & \\
\hline 10. & Mengolah limbah & Tidak & 41 & 100 \\
\hline 11. & Penghematan air dan listrik & Tidak & 41 & 100 \\
\hline
\end{tabular}

Mayoritas pekerjaan responden adalah petani mangrove (12 responden). Kelompok tani mangrove yang terlibat secara langsung bernama Kelompok Tani Bintang Timur, yang bertanggung jawab atas berbagai pekerjaan yang berkaitan dengan mangrove, seperti menyiapkan lahan, pembibitan, penanaman, perawatan, dan penyulaman. Pegawai ekowisata berjumlah sembilan responden, dengan pembagian kerja sebagai administrasi dan keuangan, loket tiket, perbaikan dan perawatan perahu, penanaman, gazebo dan dermaga. Parkir sebanyak enam responden yang mengatur ketertiban kendaraan pegunjung dan bertanggungjawab terhadap keamanan dalam kegiatan EMW. Petugas jogging track sebanyak tiga orang yang bertanggung jawab dalam mengelola jogging track Dinas Pertanian. Petugas jogging track juga bertanggung jawab untuk mengawasi kegiatan wisatawan, sehingga tidak melakukan perusakan terhadap 
ekosistem mangrove, tidak membuang sampah sembarangan, dan tidak melakukan tindakan asusila. Petugas toilet sebanyak dua responden yang bertanggung jawab atas kebersihan toilet. Staf MIC (Mangrove Information Center) sekaligus sebagai bagian hubungan masyarakat ekowisata bertanggung jawab sebagai petugas administrasi mewakili Dinas Pertanian di lokasi MIC.

\section{Pembahasan}

\subsection{Pemberdayaan Sosial}

Pemberdayaan sosial diukur melalui kualifikasi diri dan partisipasi masyarakat dalam kegiatan EMW. Peningkatan kualifikasi masyarakat yang terlibat dalam kegiatan EMW diperoleh dari adanya pelatihan (pendidikan non formal) yang telah dilakukan oleh masyarakat tersebut. Responden yang pekerjaannya sesuai dengan kualifikasi atau keahlian yang mereka miliki adalah 85,4\%. Responden mengikuti sosialisasi dan pelatihan yang dapat meningkatkan kualifikasi mereka sesuai bidang pekerjaannya, sebanyak $88 \%$ dari semua jumlah responden. Keahlian yang mereka miliki awalnya berupa autodidak atau mendapatkan keahlian dengan belajar sendiri, kemudian responden memiliki keinginan untuk meningkatkan kualifikasi yang mereka miliki. Pelatihan yang diperoleh dari berbagai pihak, seperti pemerintah (Kecamatan Rungkut, Dinas Pertanian, Dinas Pariwisata), Perguruan Tinggi (Universitas Petra, Sekolah Tinggi Ilmu Ekonomi Indonesia Surabaya, Universitas negeri Surabaya). Responden yang telah mendapatkan pelatihan kualifikasi (88\%) bersedia untuk mendapatkan pelatihan kembali sesuai dengan bidang pekerjaannya karena telah merasakan manfaat dari pelatihan yang telah diikutinya, contohnya, PKL yang awalnya tidak mengetahui cara penyajian produk makanan yang mereka jual, sekarang telah mampu menyajikan makanan dengan menarik dan terjaga sanitasinya.

Pelatihan untuk pengolahan produk dari mangrove hanya dilakukan oleh $49 \%$ dari semua responden. Pengolahan produk mangrove adalah salah keahlian yang masih jarang dimiliki. Contoh produk olahan mangrove adalah sirup dan dodol Bogem (Sonneratia caseolaris), tepung Tanjang (Bruguiera gymnorrhiza) dan lain sebagainya. Responden yang telah mengikuti pelatihan ini adalah semua petani mangrove, karena menjadi bagian dari pelatihan dan sosialisasi tentang mangrove. PKL mendapatkan pelatihan pengolahan produk mangrove untuk meningkatkan keahlian mereka dan mendapatkan keuntungan dari produk tersebut.

Responden yang berpartisipasi dalam kegiatan pengelolaan dan pengawasan EMW adalah 7\% dan sebanyak $83 \%$ responden hanya melakukan tugas sesuai pekerjaan tanpa berpartisipasi lebih lanjut dalam kegiatan EMW, dan sebanyak 10\% responden yang melakukan pengawasan. Bidang pekerjaan PKL, toilet, dan parkir adalah responden yang hanya melakukan tugas sesuai pekerjaan (83\%) dan tidak berkontribusi dalam pengelolaan maupun pengawasan pada kegiatan EMW. Responden berpartisipasi dalam pengawasan kegiatan EMW adalah 10\% dengan mengontrol kegiatan EMW supaya berjalan dengan baik, sebagai contoh ketua kelompok tani mangrove untuk mengontrol kegiatan rehabilitasi mangrove, pengelola jogging track untuk mengontrol kegiatan wisatawan dari adanya perusakan, dan pegawai ekowisata untuk mengontrol kegiatan wisata. Pengelolaan dan pengawasan dilakukan oleh pegawai ekowisata yang bertanggungjawab administrasi dan keuangan, staf MIC, dan pengelola jogging track. Ketiga responden tersebut memiliki kemampuan untuk mengawasi kegiatan yang berlangsung sesuai dengan tujuan namun tidak dapat memberikan sanksi pada pelanggaran yang terjadi.

Responden yang berpartisipasi dalam pelestarian mangrove sebanyak $80 \%$, sedangkan sisanya (20\%) tidak berpartisipasi dalam pelestarian mangrove. Partisipasi dalam pelestarian mangrove terdiri atas pembibitan, penanaman, pemeliharaan, dan pengawasan mangrove. Responden berpartisipasi dalam kegiatan pembibitan, penanaman, pemeliharaan, dan pengawasan mangrove $(68 \%)$ yang dilakukan oleh petani mangrove, pegawai ekowisata, dan jogging track. Kegiatan pembibitan dilakukan dengan cara responden turut serta dalam mempersiapkan bibit yang akan ditanam dan mempersiapkan lahan yang akan ditanami mangrove dengan membersihkan lahan tersebut dari gulma, sampah, dan mempersiapkan lubang serta ajir untuk penanaman. Pada kegiatan penanaman, responden turut serta melakukan penanaman mangrove dari lahan yang telah dipersiapkan sebelumnya, sedangkan kegiatan pemeliharaan dilakukan dengan cara penyiangan dan penyulaman, penjarangan, dan perlindungan tanaman dari hama. 
Pengawasan pada mangrove adalah dengan membersihkan sampah yang ada di sela-sela tumbuhan mangrove dan mencegah adanya perusakan oleh pihak yang tidak bertanggungjawab tanpa ikut serta secara langsung dalam kegiatan penanaman mangrove.

\subsection{Pemberdayaan Ekonomi}

Pemberdayaan ekonomi masyarakat lokal yang terlibat kegiatan EMW diukur dengan adanya peningkatan pendapatan yang diperoleh. Responden mendapatkan peningkatan pendapatan dari adanya kegiatan EMW. Responden memiliki berbagai macam pekerjaan, sebelum adanya kegiatan EMW. Responden mengungkapkan ada dua jenis pendapatan yaitu pendapat utama dan pendapatan tambahan, sebagai contoh, kelompok tani mangrove adalah buruh tambak yang merasakan bahwa penghasilan dari tambak sudah tidak dapat mencukupi kebutuhan hidupnya, sehingga menjadi petani mangrove.

Responden yang memperoleh pendapatan di bawah Rp. 1.000.000,00 berjumlah dua responden, yaitu petugas parkir. Keduanya adalah siswa SMA yang mengisi waktu luang di luar jam sekolah dengan bekerja sebagai petugas parkir. Pendapatan responden Rp. 1.000.001,00- 2.000.000,00 dengan jumlah persentase 39,0\% (16 responden) yang sebagian besar adalah pegawai ekowisata, penjaga toilet, dan parkir. Pegawai ekowisata memperoleh pendapatan di bawah UMR karena perputaran keuangan ekowisata berasal dari tiket, sedangkan pendapatan tambahan dapat diperoleh jika ada kegiatan penanaman mangrove atau kegiatan yang memanfaatkan gazebo pos pantau. Kegiatan tersebut biasanya dilakukan oleh Perguruan Tinggi, perusahaan, dan umum. Petugas parkir mendapatkan pengahasilan dari karcis parkir yag diberikan oleh Dinas Perhubungan Kota Surabaya. Tarif roda dua Rp. 2.000,00, roda empat Rp. 5.000,00, dan bus Rp. 20.000,00. Sistem yang diterapkan oleh Dinas Perhubungan adalah setoran tiap bulan dengan jumlah 3.000.000,00, sehingga pengelola menyisihkan pendapatan karcis sebesar Rp. 10.000,00 setiap hari. Uang sisa setoran karcis disisihkan 10\% untuk biaya perbaikan pos parkir, kemudian sisa pendapatan dibagikan secara merata pada petugas parkir yang berjaga pada hari tersebut. Pendapatan petugas parkir rata-rata per hari adalah Rp. 40.000,00.

Pendapatan responden Rp. 2.000.001,00- 3.000.000,00 dengan jumlah persentase 43,9\% (18 responden). Responden yang memperoleh pendapatan tersebut adalah semua petani mangrove, PKL, dan jogging track. Kelompok tani adalah pegawai kontrak Dinas Pertanian yang setiap bulan mendapatkan gaji sesuai UMR (Upah Minimum Regional) Kota Surabaya (pada tahun 2015 sebesar Rp. 2.710.000,00). Kelompok tani mendapatkan tambahan pendapatan dari adanya kegiatan penanaman yang dilakukan oleh pihak selain Dinas Pemerintah Kota Surabaya, seperti Perguruan Tinggi, sekolah, perusahaan, dan umum. Biaya pembersihan lahan untuk menanam mangrove adalah Rp. 5000,00 untuk setiap $1 \mathrm{~m} 2$. Pemilik kios (PKL) mendapatkan pendapatan bersih setiap minggu sekitar \pm Rp. 550.000,00. Responden selanjutnya yang memperoleh pendapatan Rp. 2.000.001,00- 3.000.000,00 adalah pegawai jogging track yang dikelola oleh LKMK. Pegawai jogging track memperoleh pendapatan dari karcis masuk (Rp. 2.000,00 untuk wisatawan dan Rp. 50.000,00 untuk pengambilan gambar profesional seperti pre wedding). Pendapatan bersih rata-rata pegawai jogging track setiap bulan \pm Rp. 1.750.000,00. Pendapatan responden yang lebih dari Rp. 3.000.000,00 adalah pemilik tempat makan (PKL). Tempat makan ini memperoleh pendapat lebih tinggi dari pada pemilik tempat makan yang lain karena lokasinya yang luas dan lebih nyaman bagi wisatawan.

Responden tidak menciptakan lapang pekerjaan dan berusaha secara mandiri berdasarkan uraian mengenai peningkatan pendapatan yang diperolehnya. Responden tidak terlibat secara aktif dalam perencanaan pemberdayaan secara ekonomi sehingga dapat menghasilkan pendapatan secara kreatif dan mandiri, yaitu menghasilkan produk olahan mangrove dan menjualnya sebagai buah tangan khas EMW. Responden yang telah mendapatkan pelatihan pengolahan produk mangrove (49\%) dan tidak ada satupun yang memiliki keinginan untuk memproduksinya dan dijual, karena mengganggap pengolahan produk olahan mangrove menghabiskan banyak waktu dan tenaga. Masyarakat lokal yang tidak terlibat langsung dalam kegiatan EMW ada yang memproduksi secara massal untuk produk olahan mangrove, sehingga meskipun tidak bersedia mengolah secara langsung, reponden khususnya PKL dapat menjual produk tersebut, sehingga baik masyarakat yang mengolah dan responden yang menjual mendapatkan keuntungan. Keberlanjutan secara ekonomi pada kegiatan wisata dapat diperoleh dengan adanya kegiatan 
ekonomi yang beragam dan mandiri (Fennell, 2015), namun bertentangan dengan kegiatan wisata di EMW, pemberdayaan ekonomi tidak terjadi karena tidak beragamnya kegiatan ekonomi yang ada dan tidak mandirinya pelaku yang terlibat kegiatan tersebut. Responden hanya mendapatkan peningkatan pendapatan dari kegiatan EMW dan tidak berperan aktif dalam penciptaan lapangan kerja baru.

\subsection{Pemberdayaan Ekologi}

Kegiatan ekowisata, masyarakat harus dapat menunjukkan tingkat efisiensi sumberdaya terbarukan yang mereka gunakan. Efisiensi sumberdaya terbarukan penting dilakukan untuk mengatasi peningkatan jumlah wisatawan yang menyebabkan peningkatan jumlah konsumsi sumberdaya. Kegiatan ekowisata dapat memperkenalkan kegiatan konservasi, tidak hanya pada objek wisata saja, namun juga dengan konsumsi energi yang digunakan selama melakukan kegiatan dan kunjungan wisata. Daur ulang dapat dilakukan pada limbah plastik yang dihasilkan dari kegiatan wisata dan pengolahan limbah organik menjadi kompos. Masyarakat yang terlibat dalam kegiatan EMW tidak melakukan daur ulang, maupun penghematan air dan listrik $(0 \%)$. Hal ini menunjukkan tidak adanya kesadaran terhadap pengelolaan limbah dan penghematan air serta listrik.

Perguruan Tinggi swasta di Surabaya yang mengadakan sosialisasi tentang sanitasi memberikan bantuan komposter kepada masing-masing PKL. Para pemilik kios diajarkan mengolah limbah organik menjadi kompos. Namun, komposter tersebut tidak pernah dipergunakan karena dianggap merepotkan oleh pemilik kios. Pengelola kegiatan ekowisata tidak menyediakan air bersih, sehingga pemilik kios harus membawa air bersih dari tempat tinggal ke lokasi berjualan.

Pemberdayaan ekologi yang terdapat di EMW tidak terlaksana. Menurut Winkler (2012), pendidikan memegang peranan penting dalam pemberdayaan ekologi. Penggunaan sumberdaya yang efisien mengarahkan masyarakat pada kemandirian dari penyedia sumberdaya dan nantinya mampu meningkatkan pemberdayaan ekologi dengan pengambilan keputusan secara mandiri. Hal ini bertentangan dengan yang terjadi pada kegiatan EMW. Masyarakat lokal belum mendapatkan pendidikan tentang ekologi, padahal pendidikan dapat memberikan pemahaman baru dan meningkatkan kemampuan pemberdayaan masyarakat, sehingga tidak hanya menjaga keberlanjutan mangrove sebagai objek wisata, namun juga menjaga keberlanjutan lapangan pekerjaan pada EMW. Pencapaian pemberdayaan masyakat dapat dilihat pada Tabel 2.

Tabel 2. memperlihatkan bahwa hasil analisis pemberdayaan masyarakat melalui kegiatan EMW belum tercapai. Masyarakat belum memiliki kemampuan untuk mengambil keputusan dan melaksanakan keputusan tersebut untuk mencapai tujuan kesejahteraan dari masyarakat lokal Wonorejo. Masyarakat tidak dilibatkan dalam kegiatan perencanaan dan pengembangan EMW. Masyarakat tidak diberikan pendidikan mengenai ekowisata, sehingga secara konsep masyarakat tidak memahaminya dan tidak dapat menerapkannya pada kegiatan EMW. Kondisi terkini dari pemberdayaan masyarakat pada kegiatan EMW, dari indikator yang telah diukur semuanya tidak tercapai, berarti pemberdayaan masyarakat melalui EMW tidak tercapai. Berdasarkan pendapat Boley dan McGehee (2014), pemberdayaan masyarakat menjadi prinsip utama dari pengembangan pariwisata berkelanjutan, maka tidak tercapainya indikator pemberdayaan masyarakat pada penelitian ini menunjukkan bahwa pengembangan pariwisata di EMW tidak berkelanjutan.

Pengembangan pariwisata berkelanjutan dilakukan dengan adanya peningkatan kapasitas dari berbagai pihak yang terkait dalam kegiatan tersebut. Koordinasi antar pemangku kepentingan dibutuhkan dalam membantu peningkatan kapasitas masyarakat. Pemerintah memegang peranan penting dalam peningkatan kapasitas masyarakat yang terlibat dalam kegiatan wisata karena peran pemerintah sebagai penyusun kebijakan. Pengelolaan EMW yang dilakukan Lembaga EMW secara tunggal dan belum melakukan koordinasi antar pemangku kepentingan (pemerintah, masyarakat, swasta, dan wisatawan) yang terlibat dalam kegiatan wisata. Kondisi terkini yang terjadi pada pengelolaan EMW adalah pemerintah yang belum menentukan arah kebijakan pengembangan HMW sehingga menghambat pengembangan ekowisata, hal ini diakibatkan kurangnya koordinasi antar dinas pemerintahan dalam pengelolaan HMW. 
Tabel 2. Pencapaian Pemberdayaan Masyarakat di EMW

\begin{tabular}{|c|c|c|c|c|}
\hline & Indikator & $\begin{array}{c}\text { Pengertian } \\
\text { (Winkler, 2012) }\end{array}$ & Kondisi Masyarakat di EMW & Status \\
\hline \multirow[t]{2}{*}{$\begin{array}{l}\cdot \frac{\pi}{5} \\
0 \\
0\end{array}$} & $\begin{array}{l}\text { Peningkatan } \\
\text { kualifikasi diri }\end{array}$ & $\begin{array}{l}\text { Kemampuan masyarakat } \\
\text { lokal untuk memperoleh } \\
\text { keahlian melalui } \\
\text { pendidikan, sehingga dapat } \\
\text { memecahkan masalah } \\
\text { yang dihadapi, } \\
\text { meningkatkan inisatif } \\
\text { untuk melakukan } \\
\text { konservasi lingkungan, } \\
\text { dan dapat memberikan } \\
\text { kontribusi dalam } \\
\text { peningkatan kesetaraan } \\
\text { serta kesejahteraan } \\
\text { masyarakat. }\end{array}$ & $\begin{array}{l}\text { Hasil kuesioner diperoleh } 88 \% \text { responden } \\
\text { telah mendapatkan pelatihan sesuai dengan } \\
\text { bidang pekerjaannya, namun pendidikan no } \\
\text { formal (pelatihan dan sosialisasi) yang diikuti } \\
\text { oleh masyarakat lokal belum mampu } \\
\text { berinisiatif untuk membangun kemampuan } \\
\text { dirinya secara mandiri dalam memperoleh } \\
\text { kesejahtaraan. Sebagai contoh pelatihan } \\
\text { pengolah produk mangrove yang mampu } \\
\text { menjadikan peluang usaha baru tidak } \\
\text { dimanfaatkan oleh masyarakat yang terlibat } \\
\text { langsung kegiatan EMW. }\end{array}$ & $\begin{array}{l}\text { Belum } \\
\text { tercapai }\end{array}$ \\
\hline & $\begin{array}{l}\text { Partisipasi } \\
\text { masyarakat }\end{array}$ & $\begin{array}{l}\text { Kemampuan masyarakat } \\
\text { lokal untuk mempengaruhi } \\
\text { hasil akhir dari proyek } \\
\text { ekowisata melalui } \\
\text { perencanaan, } \\
\text { pengembangan, dan } \\
\text { pengelolaan yang } \\
\text { dipercayakan pada mereka } \\
\text { untuk mencapai } \\
\text { keberlanjutan. }\end{array}$ & $\begin{array}{l}\text { Masyarakat lokal tidak dilibatkan dalam } \\
\text { perencanaan dan pengelolaan secara terpadu, } \\
\text { sehingga masyarakat tidak memiliki } \\
\text { kemampuan untuk mempengaruhi atau } \\
\text { berpendapat dalam perencanaan ekowisata } \\
\text { terbukti dari hasil kuesioner yang } \\
\text { memnunjukkan } 83 \% \text { reponden hanya } \\
\text { melakukan tugas sesuai pekerjaannya. } \\
\text { Partisipasi masyarakat hanya terbatas dalam } \\
\text { pengelolaan pelestarian mangrove, namun } \\
\text { tidak terlibat dalam perencanaannya. }\end{array}$ & $\begin{array}{l}\text { Belum } \\
\text { tercapai }\end{array}$ \\
\hline 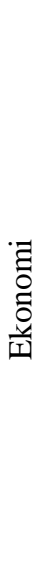 & $\begin{array}{l}\text { Peningkatan } \\
\text { pendapatan }\end{array}$ & $\begin{array}{l}\text { Kemampuan menciptakan } \\
\text { lapangan pekerjaan baru } \\
\text { dan mendapatkan } \\
\text { keuntungan dari ekowisata } \\
\text { secara merata untuk } \\
\text { mencegah terjadinya } \\
\text { konflik serta tetap } \\
\text { mempertahankan } \\
\text { keberlanjutan lingkungan. }\end{array}$ & $\begin{array}{l}\text { Pengelola ekowisata yang menciptakan } \\
\text { lapangan kerja baru, masyarakat hanya } \\
\text { dilibatkan sebagai pekerjanya saja utnuk } \\
\text { mencegah terjadinya konflik karena dikelola } \\
\text { oleh masyarakat diluar Wonorejo. } \\
\text { Masyarakat belum memiliki keinginan untuk } \\
\text { memberdayakan diri dengan menciptakan } \\
\text { lapangan kerja secara mandiri. Pemerataan } \\
\text { pendapatan juga tidak terjadi, meskipun } \\
\text { masyarakat lokal mendapatakan peingkatan } \\
\text { pendapatan. Masyarakat tetap menjaga } \\
\text { mangrove sebagai objek wisata ditempat } \\
\text { mereka bekerja untuk keberlanjutan } \\
\text { pekerjaannya, bukan untuk keberlanjutan } \\
\text { lingkungannya. }\end{array}$ & $\begin{array}{l}\text { Belum } \\
\text { tercapai }\end{array}$ \\
\hline $\begin{array}{l}\overrightarrow{00} \\
\frac{0}{0} \\
\frac{y}{\square I}\end{array}$ & $\begin{array}{l}\text { Efisiensi } \\
\text { sumberdaya }\end{array}$ & $\begin{array}{l}\text { Kemampuan masyarakat } \\
\text { lokal untuk meningkatkan } \\
\text { penggunaan sumberdaya } \\
\text { terbarukan dan } \\
\text { peningkatan kesadaraan } \\
\text { terhadap keberlanjutan } \\
\text { lingkungan melalui } \\
\text { penghematan penggunaan } \\
\text { energi }\end{array}$ & $\begin{array}{l}\text { Masyarakat lokal yang terlibat dalam } \\
\text { kegiatan ekowisata tidak melakukan } \\
\text { efiesiensi sumberdaya, daur ulang, } \\
\text { penghematan air, dan listrik. Pengelola tidak } \\
\text { menyediakan air bersih dan listrik bagi } \\
\text { kegiatan operasional EMW. Pengelola juga } \\
\text { tidak mensosialisasikan kegiatan daur ulang } \\
\text { limbah bagi masyarakat yang terlibat } \\
\text { kegiatan EMW. }\end{array}$ & $\begin{array}{l}\text { Belum } \\
\text { tercapai }\end{array}$ \\
\hline
\end{tabular}




\section{Kesimpulan}

Berdasarkan hasil penelitian yang telah dilakukan dapat disimpulkan bahwa pemberdayaan fennel Ecotourism 4th Edition 2015 masyarakat yang diukur melalui pemberdayaan sosial, ekonomi, dan ekologi tidak tercapai. Pemberdayaan sosial yang diukur melalui peningkatan kualifikasi diri dan pastisipasi masyarakat diketahui bahwa masyarakat belum mampu berinisiatif untuk membangun kemampuan dirinya secara mandiri dalam memperoleh kesejahtaraan dan masyarakat tidak dilibatkan dalam perencanaan dan pengelolaan secara terpadu. Pemberdayaan ekonomi diperoleh berdasarkan peningkatan pendapatan masyarakat dari gaji yang diterima setiap bulannya karena masyarakat belum memiliki keinginan untuk memberdayakan diri dengan menciptakan lapangan kerja secara mandiri. Pemberdayaan ekologi, masyarakat tidak melakukan efiesiensi sumberdaya, daur ulang, penghematan air, dan listrik.

\section{Daftar Pustaka}

BLH. (2013). Profil Keanekaragaman Hayati Kota Surabaya. Badan Lingkungan Hidup Kota Surabaya, Kementerian Lingkungan Hidup Republik Indonesia.

Boley, B. B., \& McGehee, N. G. (2014). Measuring empowerment: Developing and validating the resident empowerment through tourism scale (RETS). Tourism Management, 45, 85-94.

BPS Kota Surabaya. (2015). Kota Surabaya Dalam Angka 2015. Surabaya, Indonesia: Badan Pusat Statistik Kota Surabaya.

Fennell, D. A. (2015). Ecotourism. ( $4^{\text {th }}$ Ed.). New York, USA: Routledge.

Phillips, R., \& Pittman, R. (2008). An introduction to community development. New York, USA: Routledge.

Sadan, E. (2004). Empowerment and Community Planning. (E-Book Edition). Tel Aviv, Israel: Hakibbutz Hameuchad Publishers.

Sutawa, G. K. (2012). Issues on Bali tourism development and community empowerment to support sustainable tourism development. Procedia economics and finance, 4, 413-422.

Winkler, M. T. (2012). Ecotourism as Community Development Tool: Development of an Evaluation Framework. Master Thesis. Graz, Austria: Department of Geography and Regional Science, University of Graz.

Yoeti, O. A. (2000). Ekowisata: Pariwisata Berwawasan Lingkungan Hidup. Jakarta, Indonesia: PT Pertja. 